INTERNATIONAL JOURNAL OF RESEARCHES IN BIOSCIENCES, AGRICULTURE AND TECHNOLOGY (C) VISHWASHANTI MULTIPURPOSE SOCIETY (Global Peace Multipurpose Society) R. No. MH-659/13(N) www.vmsindia.org

\title{
EFFECTS OF DIETARY GARLIC ON GROWTH PERFORMANCE IN THE FRESH WATER FISH CLARIAS BATRACHUS (LINN.)
}

\author{
R. A. Gulhane ${ }^{1}$ P.S. Joshi ${ }^{2}$ and V. T. Tantarpale ${ }^{2}$ \\ ${ }^{1}$ S.S.S.K.R.I. Mahavidyalaya, Karanja (M.S.) India \\ 2Vidyabharti Mahavidyalaya, Amravati (M.S.) India
}

Abstract:

The aim of this study was to assess the effect of garlic (Allium sativum) on growth performance in the fresh water fish Clarias batrachus (Linn.) A total number of 80 fish (average weight $20.86 \pm 0.27 \mathrm{~g}$ ) was used. Fish were divided into four groups fed on diets containing garlic in different levels and the control group diet was without garlic. The experiment extended for two months. The results showed that, significant weight gain and growth performance increased in all groups fed on garlic. The results of this study show that addition of garlic Allium sativum to fish diet can promote growth of fish.

Keywords: garlic (Allium sativum), growth factors, fresh water fish (Clarias batrachus).

\section{Introduction}

Feed and feeding are among the most important factors influencing growth, feed utilization and tissue composition of the fish in intensive culture (Okumus and Mazlum, 2002). Garlic is an important vegetable extensively cultivated in many countries. It is used as food for humans as well as some animals and as remedy for several diseases, as reported in folk medicine (Shalaby et al., 2006). It is probably one of the earliest known medicinal plants. In recent years, the concern about bacterial resistance to antibiotics in livestock industry has led to legislation minimizing/eliminating the use of such compounds. Garlic contains sulfur containing compounds. Alliin, is converted to the antimicrobial active allicin, when the bulb is cut or bruised. The fresh bulb contains Alliin, Allicin and volatile oils. Allicin gives garlic its characteristic pungent smell. Also, it contains vitamins and minerals and trace elements (selenium and germanium) (Skidmore-Roth, 2003). Allicin (diallythiosulfinate) is the most abundant compound representing about $70 \%$ of all thiosulfinates present, or formed in crushed garlic (Block, 1992; Han et al., 1995). Using of garlic in fish farming has become popular for as a growth promoter (Diab et al., 2002; Metwally, 2009) also it increased body gain, feed intake and feed efficiency ratio (Abd-El Allatif and Ebraheem, 1996; Metwally, 2009).

This work was carried out to study the effect of different values of garlic on growth factors in Clarias batrachus.

\section{Material and Methods}

1. Experimental fish: The Clarias batrachus $(20.88 \pm 0.25$ g) were obtained from a commercial farm and were transferred to the place of experiment and acclimated for 2 weeks. During the acclimation, fish were fed the experimental diet to satiation twice a day at 09:00 and 15:00 hours. After acclimation, fish were fasted for one day; batch weighted and randomly distributed among density of 20 fish per tank.

2.Experimental diet and feeding regime: The basal experimental diets were formulated with the commonly available ingredients. The formula and analyzed proximate composition of the basal diet are shown in Table 1. The ingredients were grinded, milled, weighed, mixed and pelleted with meat mincer through a $2 \mathrm{~mm}$ die. After pelleting, the feeds were air dried and put in an air-tight container. During the experiment, fish were fed the experimental diet to satiation third a day at 08:00, 12:00 and 16:00 hours.

3.Measurements and sample analysis: It was carried out each 20 days. Water temperature was $15^{\circ} \mathrm{C}$, O2 $7-8$ mgl-1, pH 7-8 and light: dark cycle of $12: 12 \mathrm{~h}$ was maintained during the feeding trial. Proximate composition of diets and tissues were carried out using the Association of Analytical Chemists (AOAC, 2000) methods.

4.Calculations and statistical analysis: The following variables were calculated:

a) Body weight increase $(\mathrm{BWI})=\mathrm{Wt}-\mathrm{WO}($ Tacon, 1990)

b) Specific growth rate $(\mathrm{SGR})=(\ln \mathrm{Wt}-\ln \mathrm{W} 0) \times$ $100 \mathrm{t}^{-1}$ (Hevroy et al., 2005)

Where, Wt and WO = Final and initial fish weights (g), respectively,

$(\mathrm{t})=$ the experimental period in da

c) Feed conversion ratio $(\mathrm{FCR})=\frac{\text { Total dry feed consumed }(\mathrm{g})}{\text { total weight gained }(\mathrm{g})} \quad$ (Shalaby et al., 2006)

d) The data obtained from the trial is expressed as mean $( \pm \mathrm{SD})$.

\section{Results and Discussion:}


Growth performances of the fishes after 60 days of feeding are summarized in Table 2. Third fish group had higher final weight, weight gain, and SGR than fish fed on other levels of garlic and control. The highest amounts of dry feed intake (g/fish/day) were seen in the same third fish groups. Results also show that FCR decreased significantly to $1.39 \pm 0.01$ in the third group.

It is clear that garlic is a main vegetable extensively cultivated in many countries. It is used as food for humans as well as some animals and as remedy for several diseases, as reported in folk medicine (Shalaby et al., 2006). In this study the highest growth performance was observed in fish fed diets containing garlic, especially on $30 \mathrm{~g}$ garlic. It agrees with studies results of Diab et al., (2002), Abou-Zeid, (2002), Shalaby et al., (2006). Feed intake increased with increasing Allium sativum levels. Feed conversion ratio decreased with increasing Allium sativum levels. These results are also in agreement with those obtained by Gomes et al., (1993), Degani et al., (1997), Khattab et al., (2004) and Farahi et al., (2010).

\begin{tabular}{|l|l|l|l|l|}
\hline Table 1. Formulation and proximate composition of the basal fish diets \\
\hline Ingredients & Control & Allium sativum diets Ingredients (g 100g diet) \\
\hline Meat & 25 & 25 & 25 & 25 \\
\hline Wheat & 50 & 47 & 44 & 41 \\
\hline Soybean & 20 & 20 & 20 & 20 \\
\hline Soybean oil & 05 & 05 & 05 & 05 \\
\hline Garlic & 00 & 03 & 06 & 09 \\
\hline
\end{tabular}

\begin{tabular}{|l|l|l|l|l|}
\hline \multicolumn{5}{|l|}{ Table 2: Effects of garlic on growth parameters in fish fed on experimental diets $(\mathrm{g} / 100 \mathrm{~g})$} \\
\hline Parameters & Control & I & II & III \\
\hline Initial weight $(\mathrm{g})$ & $20.87 \pm 0.30$ & $20.83 \pm 0.09$ & $20.85 \pm 0.34$ & $20.89 \pm 0.33$ \\
\hline Final weight $(\mathrm{g})$ & $97.05 \pm 3.10$ & $105.76 \pm 4.12$ & $111.51 \pm 4.23$ & $115.88 \pm 2.51$ \\
\hline BWI $(\mathrm{g})$ & $76.81 \pm 3.39$ & $86.81 \pm 4.13$ & $90.03 \pm 4.56$ & $98.02 \pm 3.42$ \\
\hline SGR & $1.53 \pm 0.06$ & $1.62 \pm 0.05$ & $1.68 \pm 0.04$ & $1.71 \pm 0.03$ \\
\hline FCR & $1.61 \pm 0.05$ & $1.45 \pm 0.04$ & $1.43 \pm 0.05$ & $1.39 \pm 0.01$ \\
\hline Feed intake $(\mathrm{g})$ & $119.12 \pm 1.29$ & $123.35 \pm 2.31$ & $127.24 \pm 1.33$ & $133.02 \pm 2.12$ \\
\hline
\end{tabular}

Figure 1.(a to f): Effects of garlic on growth parameters in fish fed on experimental diets

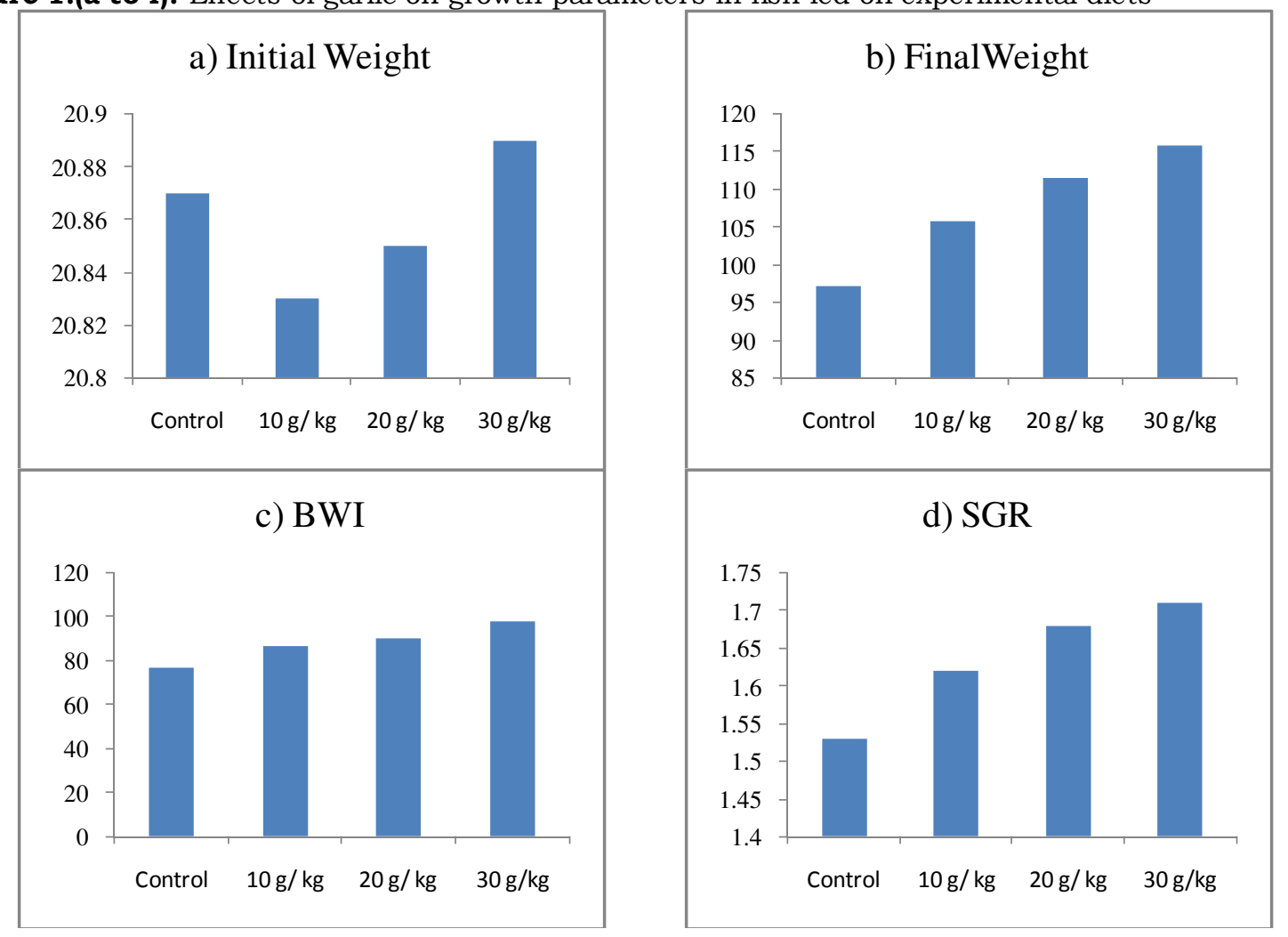




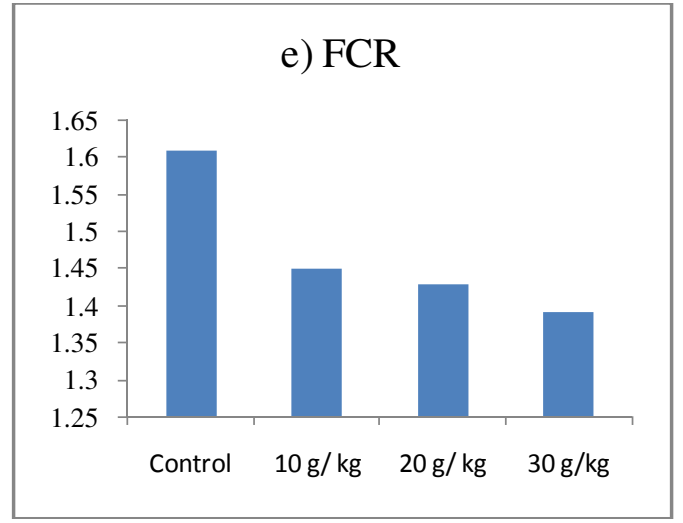

\section{Conclusions}

From obtained results, it could be recommended that garlic (Allium sativum) can be used as a growth promoter in Clarias batrachus so garlic should be added to the diets of fish.

\section{References:}

Abd-E1 Allatif A. and K. Ebraheem (1996): Studies on the effects of Hibiscus subdariffa, Allium sativum and Negella sativa on some bacterial isolates of chickens. Fac Vet Med Assute University Egypt. 17:245-251.

Abou-Zeid S. M. (2002): The effect of some medical plant on reproductive and productive performance of Nile tilapia fish. Cairo: Cairo University, Faculty of Agriculture, 212p. [PhD Thesis]

Block E. (1992): The organ sulfur chemistry of the genus Allium implications for the organic chemistry of sulfur. Angew Chem Int. 31:11351178.

Degani G., Viola S., and Y. Yehuda (1997): Apparent digestibility of protein and carbohydrate in feed ingredients for adult tilapia (Oreochromis aureus X Oreochromis niloticus). Isr $J$ Aquac. 49:115-123.

Diab A. S., E1-Nagar G. O. and Y. M. Abd-E1Hady (2002): Evaluation of Nigella sativa L (black seeds; baraka), Allium sativum (garlic) and BIOGEN as feed additives on growth performance and immunostimulants of Oreochromis niloticus fingerlings. Suez Canal Vet Med J. 2002:745-775.

Farahi A, Milad K, Mohammad S, Mohsen S. and M. Shahkolae (2010): Effect of garlic on some hematological parameters and body compositions in rainbow trout (Oncorhynchus mykiss). AACL Bioflux, 3 (4): 317-323

Gomes E. F., Corraze G. and S. J. Kaushik (1993): Effect of dietary incorporation of a coextruded plant protein (rapeseed and peas) on growth, nutrient utilization and muscle fatty acid composition of rainbow trout (Oncorhynchus mykiss). Aquaculture 113:339353.

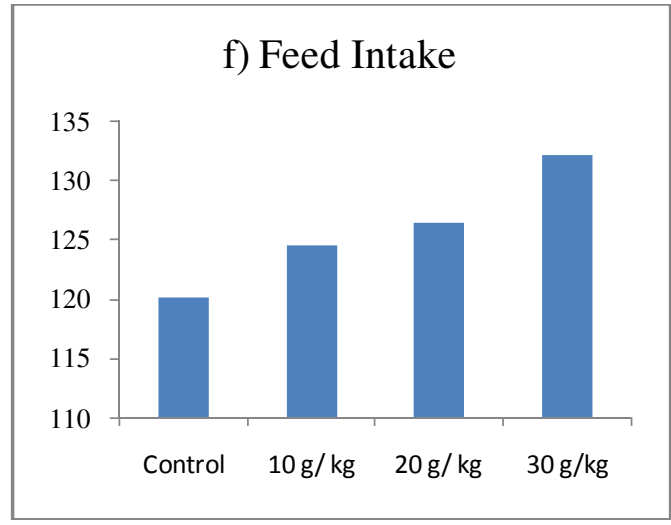

Han J., Lawson L., Han G. and P. Han (1995): A spectrophotometric method for quantitative determination on allicin and total garlic thiosulfnates. Anal Biochem. 225:157-160.

Hevroy E. M., Espe M., Waagbo R., Sandness K., Rund M. and G. Hemre (2005): Nutrition utilization in Atlantic salmon (Salmo salar) fed increased level of fish protein hydrolyses during a period of fast growth. Aquacul Nutr. 11:301313.

Khattab Y. A., Shalaby A. M. E., Sharaf S. M., E1-Marakby H. I. and E. H. Rizkalla (2004): The physiological changes and growth performance of the Nile tilapia Oreochromis niloticus after feeding with Biogen as growth promoter. Egypt J Aquat Biol and Fish. 8:145158.

Metwally M. A. A. (2009): Effects of garlic (Allium sativum) on some antioxidant activities in tilapia nilotica (Oreochromis niloticus). World $J$ of Fish and Marine Sci.1:56-64.

Okumus I. and M. Mazlum (2002): Evaluation of commercial trout feeds: Feed consumption, growth, feed conversion, carcass composition and bioeconomic analysis. Tur $J$ of Fish and Aqua Sci 2:101-107.

Shalaby A. M., Khattab Y. A. and A. M. Abdel Rahman (2006): Effect of garlic (Allium sativum) and chloramphenicol on groth performance, physiological parameters and survival of Nile tilapia (Oreochromis niloticus). J Venom Anim Toxins incl Trop Dis. 12(2):172-201.

Skidmore-Roth L. (2003): Handbook of Herbs and Natural Supplements. 2nd Edn. St. Louis: Mosby.

Tacon A. G. J. (1990): Standard method for nutritional and feeding of farmed fish and shrimp. Argent librations press, Vol 1: 117pp.

Williamson E. (2003): Potter's Herbal Cyclopaedia,. C.W. Daniel Publication, London 